UDK: 929Панзова, В.

\title{
THE UNIFYING POWER OF THE LOGOS In Memory of Professor Violeta Panzova
}

Everyone who has had the opportunity to experience the most valuable aspect of the educational process - that is, its influence on the shaping and flourishing of the human potential of the individual - seems to be able to capture, albeit intuitively, the deep, philosophical meaning of the term "teacher". In this meaning, it refers not only to a professional, but also - or even primarily - to a spiritual category. A teacher is a person who, through words and deeds, reveals to us the true meaning of the lifelong activity of learning, understood as a process of self-development and self-actualization, as recognizing the unique ontological "gift of the self" and nurturing it towards achieving its optimal form. It is a process based on the acquisition of knowledge of various kinds, but always inspired by the ethical pursuit of the good and aimed at establishing a delicate balance between one's own and other persons' perspectives.

Hence, a true teacher is one who never stops learning, one who is able to learn from all life situations and from all persons, and especially from his or her students. A true teacher is one who has the power to revive the spiritual spark present in everyone's mind, the spark of curiosity, wonder and admiration of the secrets of the world that are yet to be discovered. That is why our teachers, in the broadest sense of the word, can be both the young and the adults, the known and the unknown, the living and those who have already left this world. Our teachers are all those who have shown us what it means to carry inside oneself the seed of spiritual aspiration and the impenetrable core of personal integrity, whether or not their knowledge and teaching abilities are formally verified. But that is why - for an even stronger reason - it is essential for all individuals that have decided to choose education in a formal, institutional sense for their profession, to never forget or neglect their most important, but also most difficult mission - the ethically inspired teaching mission. Without its subtle and precious threads, the social and personal power concentrated in even the most prestigious professors' positions remains deprived of its foundation and can easily degenerate in its opposite. But when the personality of a great professor is naturally and inseparably merged with the personality of a great teacher, it becomes a centre of positive, inspiring social dynamics and intellectual influence, whose fruits are the most rewarding outcome of the human interaction within the educational process.

Such a combination of a professor's and teacher's ethos, based on the commitment to the intellectual, as well as the human dimension of the academic activity, is one of the most striking features of the life and work of Profes- 
sor Violeta Panzova, retired full professor at the Institute of Philosophy at the Faculty of Philosophy within the Ss. Cyril and Methodius University in Skopje (UKIM). With her sudden death on April 7, 2020, at the age of 71, the Macedonian philosophical thought lost one of its most prominent representatives. She was a person who incorporated all of her scientific and pedagogical potentials in the foundations of the Faculty of Philosophy and in the wider corpus of the Macedonian philosophical and scientific culture, to the promotion of which she has dedicated her entire professional life.

Violeta Panzova was born in 1948 in Sveti Nikole. She completed her primary and secondary education in her hometown, with excellent success. Her outstanding intellectual talent and diligence were manifested as early as her high school days; thus, she completed the studies of the third and the fourth class of high school in one year (1966).

She graduated from the Philosophy Department at the Faculty of Philosophy in Skopje (1970) and received her Master's degree from the Faculty of Philosophy in Belgrade (1981), where she also received her PhD (1989). She was a full-time employee of the Faculty of Philosophy in Skopje since 1971, first as an intern-assistant, and then as a lecturer (1982), assistant professor (1990), associate professor (1995) and full professor (since 2000). She was the head of the Institute of Philosophy at the Faculty of Philosophy from 1995 to 1999. During her many years of work as a university teacher, she taught a number of courses in the fields of Logic, Epistemology, Methodology, Philosophy of Language and related philosophical disciplines in the framework of all three cycles of studies - undergraduate, postgraduate and doctoral studies, at the Faculty of Philosophy and at other faculties within the UKIM University. These courses were attended and successfully completed by more than 20,000 students.

Professor Violeta Panzova was a member of committees for defence of a number of master's theses and doctoral dissertations at the Faculty of Philosophy, as well as at other university institutions in the country and abroad. Under her mentorship, several master's theses and doctoral dissertations in the fields of logic and epistemology were prepared and defended.

She was a leader of several scientific research projects, including: "Logical Analysis and Formalization of the Macedonian Standard Language" (19921995), "Contemporary Trends in Argumentation Theory" (1998-2000) and "Macedonian Logical Terminology" (2000-2003). She participated in many scientific conferences, symposia and other scientific events in the country and abroad with her lectures, papers and presentations. Professor Panzova published around one hundred scientific articles in domestic and foreign periodicals and nine books: Универзалната граматика и македонскиот јазик [Universal Grammar and the Macedonian Language] (1996); Значеньето и вистината, уред. [Меaning and Truth, ed. ] (1998); Логика - општа теорија на рационалноста [Logic a General Theory of Rationality] $(1999,2002)$; Семантичките парадокси [Semantic Paradoxes] (2001); Науката како занает [Science as a Craft] (2003); Логика за 4 година на реформирано гимназиско образованиеl Logjika përvitin 4 të gjimnazit 
tëreformuar [Logic for the $4^{\text {th }}$ year of the reformed gymnasium] (2005); Логичкu лексикон [A Lexicon of Logic] (2005), Прирачник за изработка на студентски трудови [Manual for Preparation of Student Papers] (2007, 2011); Вештината на истражуването - општите постапки во научната работа [The Art of Research - General Procedures in the Scientific Work] (2018).

In 2006, Professor Violeta Panzova received the highest state award "11 Октомври" [“October 11"] - for outstanding long-term achievements in the fields of education and science.

Through her numerous academic papers, as well as through her public speeches and lectures, Professor Violeta Panzova systematically developed her original concept of logic, understood as a general theory of rationality, whose elements are embedded in all fields of human intellectual and practical activity. Her approach to logic was based on the idea that it was not an esoteric discipline whose formal-symbolic "secrets" are accessible only to a few. On the contrary, she consistently affirmed the idea of the unifying power of logic as the intellectual fabric of our common rational nature, which enables us to communicate in a meaningful way, and to bring our diverse perspectives closer together. However, as an equally important aspect of the study of logical mechanisms and instruments of reasoning, Professor Panzova constantly emphasized the need to cultivate their proper dialectical use, which includes the ethical aspects of knowledge and communication. Her narrower scientific interests were related to the application of modern logic in the analysis and digitalization of natural languages, with special emphasis on the Macedonian language, for which she developed a new logical apparatus.

Through her scientific research and teaching activity, Professor Violeta Panzova created a solid foundation for further advancement of logical-philosophical research in our intellectual milieu. In this context, a particularly important aspect of her work was the concern for building the professional capacities of new generations of researchers and thinkers. This concern was manifested primarily through her works in the fields of logic, methodology and technique of scientific research, in which intellectual tools were developed and presented that are extremely useful for all researchers in the scientific and philosophical disciplines. Besides that, Professor Panzova's contribution to the building of independent and competent critical thinkers was also realized through the pedagogical values of professionalism, high standards, respect, cooperation, as well as through her direct and honest communication with the students. In that way, she enriched the Macedonian philosophical-logical thought both by her scientific achievements and by her practicing of the educational activity as a process of mutual advancement of the persons involved in it. Hence, Professor Violeta Panzova will be remembered forever by her colleagues, friends and many generations of students not only as a philosopher, logician and professor of the highest rank, but also as a teacher and educator in the deepest, human sense of the word. 